\title{
Transplanting date adjustment in Boro rice cultivation as a strategy to reduce groundwater withdrawal in Bangladesh
}

\author{
Md. Hossain Ali \\ Bangladesh Institute of Nuclear Agriculture Mymensingh, BANGLADESH \\ *Corresponding Author email: mha_bina@yahoo.com
}

Doi: $10.2478 / m j h r-2019-0006$

\begin{abstract}
:
Due to intensive irrigated rice cultivation during dry season, declining trend of groundwater level is observed in many parts of Bangladesh. Field experiments were conducted in 2015 and 2016 at four experimental stations of Bangladesh Institute of Nuclear Agriculture, Bangladesh to evaluate the performance of some Boro rice cultivars in different planting dates with respect to yield and irrigation water requirement, and to optimize between yield and irrigation water requirement, with a view to reduce groundwater withdrawal and hence reducing mining of groundwater. The transplanting dates were 21th January (T1), 15th February (T2), 7th March and 30th March. Four rice cultivars were used. The results showed that the rice growth period was shortened with the later dates of transplanting. Generally, the yield of all cultivars at first and second transplanting (i.e. in T1 \& T2) are good, and decrease at the later transplanting dates (T3, T4) and hence could not be recommended among farmers. When we consider the irrigation savings in T2 compare to $\mathrm{T} 1$, the irrigation savings varies with location and year, but the general tendency is that the second transplanting can save irrigation water. By considering economic (intrusion of additional rabi crop between two rice crops) and ecological factor (irrigation reduction, and hence reducing groundwater withdrawal), we recommend that the most suitable transplanting time for Boro rice should be 15 th February. As such, we can effectively achieve good yield, reduce irrigation requirement, and creating opportunity for possible intrusion of addition Rabi crop between two rice crops. Overall, the findings of the present study can provide effective transplanting time and cultivar to reduce groundwater withdrawal in the present agro-ecosystem of northwestern Bangladesh and other similar areas.
\end{abstract}

Keywords: Boro rice, irrigation requirement, transplanting date, groundwater withdrawal, ecosystem

\subsection{Introduction:}

In the rain-fed farming systems of arid and semi-arid regions, water stress is the main limiting factor for crop production. Water resources are becoming scarce worldwide [1,2]. Bangladesh is no exception [3-5]. Bangladesh contains world's one of the largest delta and is, therefore, heavily depends on rivers originating in other countries and rainfall for its water supply. Climate change (rise in temperature and changing rainfall patterns), deforestation and construction of dams in common rivers have led to a reduced amount of water entering into Bangladesh [6]. As surface water supply is decreasing day by day, irrigation pressure is going towards groundwater resource. But this resource is not unlimited. In intensive tube well areas, water level is declining gradually in dry season [7-9]. Climate change has worsen the situation [10,11]. So, the judicious use of water resources in intensive irrigated area is a crucial need for maintaining sustainable crop production.

Rice is one of the major consumers of water in agricultural sector. However, the sources of fresh surface water are limited and casing dependent on groundwater. It has been estimated that about $3000-5000$ litres of water is required to produce one kilogram of rice [12,13]. Intensive rice cultivation during dry, Boro season to feed the increasing population of the country have contributed to excessive groundwater withdrawal in many parts of Bangladesh [14]. This situation of groundwater may cause a great threat for future groundwater availability for irrigation, and ultimately for sustainable Boro production which contributes major share of total rice production. In a situation of higher demand of rice (due to increasing population), there is no alternate choice but to produce more rice. In terms of solar radiation, the period from November to April is more suited for crop production [15,16]. For Boro-rice, irrigation is indispensable, as the entire growing season falls within the dry period $[17,18]$. There is a great need to increase the productivity of water in rice irrigation systems in a sustainable way [19]. If the water demand is partially meet by rainfall, the irrigation cost is reduced and also the pressure on dwindling groundwater resource is lessened. In this context, a suitable transplanting date of rice should be determined which can maintain potential or acceptable yield with reduced irrigation water.

A group researchers investigated the efficacy of different planting dates (PDs) on rainfed maize yield and water-use efficiency in semi-arid region of China [20]. They found that, within a certain time range, dry matter production per plant did not obviously change across PDs. However, the dry matter accumulation in the ear after flowering, the yield, and the WUE in the treatments under appropriate PDs were higher than those in the early or delayed PDs. Other group of researchers observed the yield, water productivity and economic returns of malt barley following different sowing dates and supplemental irrigation [21]. They found that in terms of water use, sowing by mid-November is advantageous since more rainfall is generally available. Some researchers conducted field study under the semi-arid environment of Faisalabad, Pakistan [22]. They observed significant differences among different transplanting dates of wet-season rice, as well as among cultivars. They explored that late transplanting caused yield reduction which could not be recommended among farmers.

For rice, information on different transplanting date and its effects on irrigation requirement and water use efficiency is scarce in Bangladesh. The frequency and total amount of irrigation for the growing season depends on the soil type, cultivar (maturity period, drought resistance capacity), ET demand, and rainfall availability $[3,23,24]$. Thus, it is not appropriate to make definite recommendation regarding the number and amount of irrigation to be applied for all cultivars under diverse planting dates. Utilization of rainwater without sacrificing yield can reduce valuable ground water withdrawal, which is desirable for sustainability of the resource in the region [14].

Therefore, the present experiment was designed to evaluate the performance of some Boro rice cultivars in different planting dates with respect to yield and irrigation water requirement, and to optimize between yield and irrigation water requirement, with a view to reduce groundwater withdrawal and hence reducing mining of groundwater.

\subsection{Materials and methods}

\subsection{Description of the experimental site}

The experiment was conducted at four experimental stations of Bangladesh Institute of Nuclear Agriculture (BINA), Bangladesh, covering different agroecological and hydrological regions (Figure 1). The latitude and longitude of the areas and main features are provided in Table 1. 


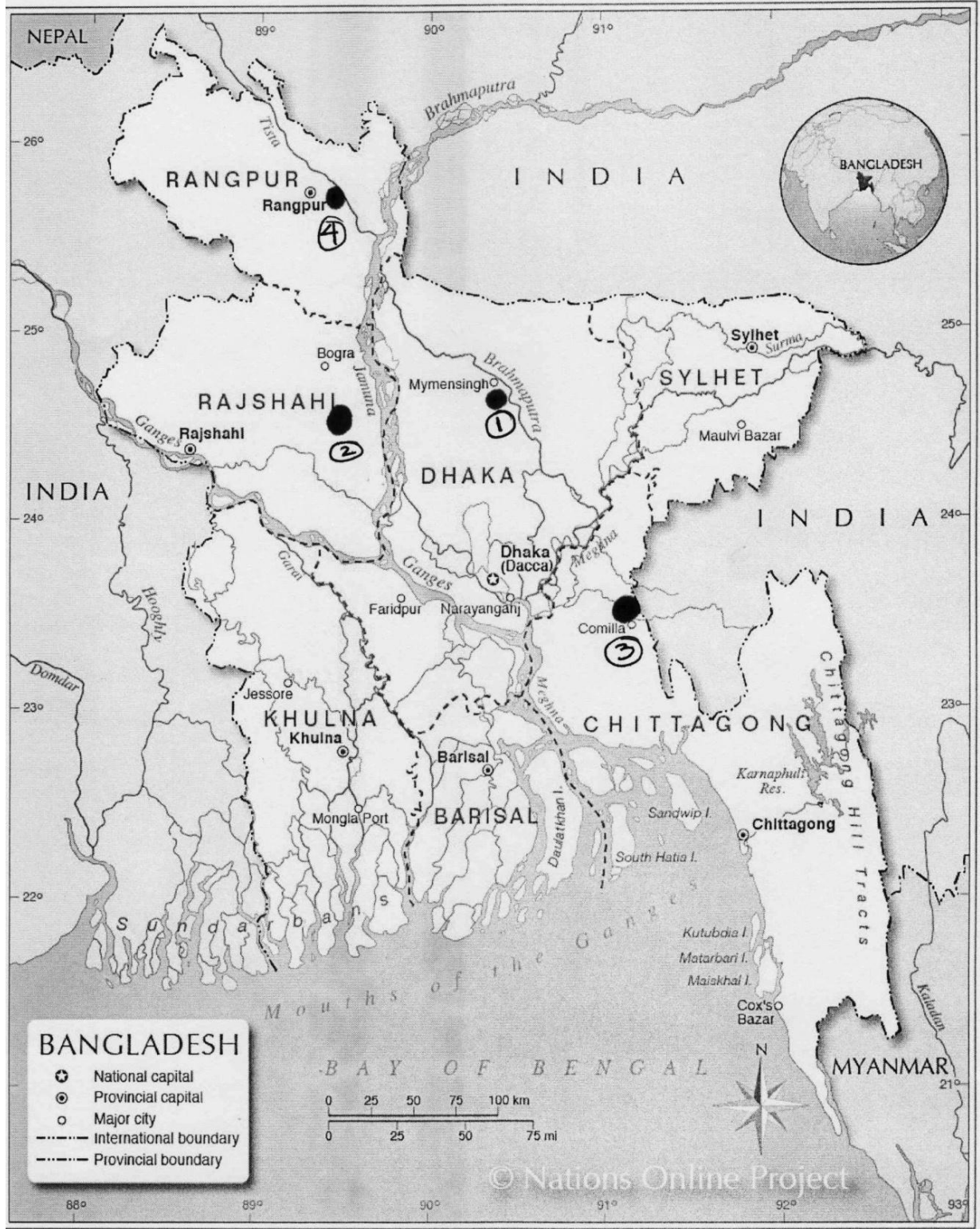

Figure 1: Location map of the study area $(\bullet$ black marked)

Table 1: Latitude, longitude and main characteristics of the study sites

\begin{tabular}{|l|l|l|l|l|l|}
\hline Sl & $\begin{array}{l}\text { Location/ } \\
\text { Station }\end{array}$ & $\begin{array}{l}\text { Latitude } \\
\text { (degree) }\end{array}$ & $\begin{array}{l}\text { Longitude } \\
\text { (degree) }\end{array}$ & $\begin{array}{l}\text { Altitude } \\
\text { (Above Mean } \\
\text { Sea Level) (m) }\end{array}$ & Main characteristics of the area \\
\hline 1 & Mymensingh & $24^{0} 43^{\prime}$ & $90^{0} 26^{\prime}$ & 6 & Medium land, alluvial deposit, loamy soil \\
\hline 2 & Ishwardi & $24^{0} 08^{\prime}$ & $89^{\circ} 03^{\prime}$ & 15 & Relatively highland, calcarious soil, dry region \\
\hline 3 & Cumilla & $23^{0} 28^{\prime}$ & $9^{0} 10^{\prime}$ & 9 & Medium land, loamy soil \\
\hline & Rangpur & $25^{0} 45^{\prime}$ & $8^{0} 15^{\prime}$ & 34 & Relatively cool weather, sandy loam soil \\
& & & & & \\
\hline
\end{tabular}

\subsection{Experimental design and field management}

The experiment was conducted during Boro season (Jan.-June) of 2015 and 2016. The design was Randomized Complete Block (RCB) with split-plot arrangement. The main plot treatments (time of transplanting for saving irrigation) were: T1= Transplanting on 21th January and irrigation at 3 days after disappearance of ponded water (DADPW); T2= Transplanting on 15th February and irrigation at 3 DADPW, T3= Transplanting on 7th March and irrigation at 3 DADPW, T4= Transplanting on 30th March and irrigation at 3 DADPW. The Sub-plot treatments (cultivars) were: V1 = Binadhan-14, V2 = BRRIdhan 29, V3 = BRRIdhan 28. The cultivar V4 = Binadhan-10, was added in second year. In Bangladesh, in general, the temperature and hence the heat unit and ET0 increse from the first transplanting (21st January) to onward (Figure 2). 


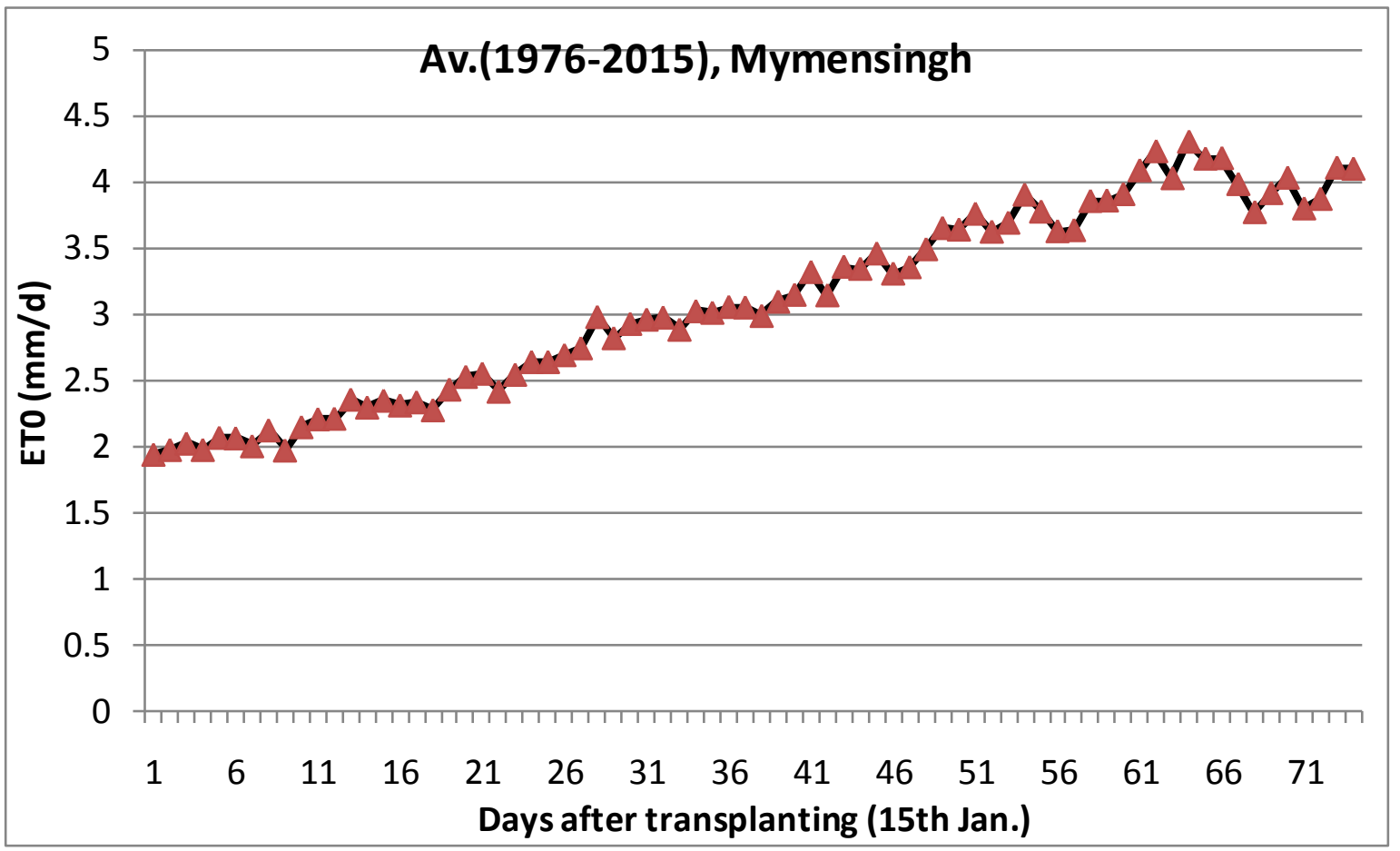

Figure 2: Long-term ET0 pattern during crop-season in Mymensingh, Bangladesh

\subsection{Climate and rainfall distribution}

The climate of the regions falls within humid sub-tropic with summer dominant rainfall. The annual rainfall at the study sites varies from $1500 \mathrm{~mm}$ to 3300 $\mathrm{mm}$; approximately $70 \%$ of this rainfall occurs during the months of May to August, which is noted as monsoon season.

\subsection{Fertilization, Irrigation and management}

The seedlings of rice were transplanted according to the scheduled treatments. Each plot was fertilized uniformly with basal dose of Triple super phosphate, Muriate of Potash, Gypsum, and Zinc by 80, 110, 70, 45, $4.5 \mathrm{~kg} \mathrm{ha}^{-1}$, respectively. Urea was applied in three equal splits by $70 \mathrm{~N} \mathrm{ha}^{-1}$ at 10,30 and 45 days after transplanting. Measured amount of water was applied in each plot through water-meter, attached at the outlet point of rubber hose pipe. All cultural practices were followed as and when necessary. The grain and straw yields were adjusted to $12 \%$ moisture content following the equation [25]:

$Y_{a d j}=Y_{i} * \frac{\left(100+M_{t}\right)}{\left(100+M_{i}\right)}$

where $\mathrm{M}_{\mathrm{i}}$ the initial moisture content, $\mathrm{Y}_{\mathrm{i}}$ the initial yield (at $\mathrm{M}_{\mathrm{i}}$ moisture content), $\mathrm{M}_{\mathrm{t}}$ the targeted moisture content (say, $12 \%$ ), and $\mathrm{Y}_{\text {adj }}$ the adjusted yield (at $\mathrm{M}_{\mathrm{t}} \%$ moisture content).

\subsection{Data analysis}

The analysis of variance technique (ANOVA) was carried out on the data. The software "STAR", developed by International Rice Research Institute (IRRI), was used to analyze the data. The significance among the means of the treatments was determined using least significant difference (LSD) technique at $5 \%$ probability level.

\subsection{Results and Discussion}

3.1 Year 2015

Table 2.1: Effect of treatments (transplanting time) on grain yield at each level of cultivars (2015)

\begin{tabular}{|c|c|c|c|c|}
\hline \multirow[t]{2}{*}{ 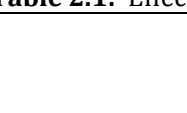 } & \multirow{2}{*}{ Treatment } & \multicolumn{3}{|c|}{ Cultivars } \\
\hline & & $\begin{array}{l}\text { V1 } \\
\text { (Binadhan-14) }\end{array}$ & $\begin{array}{l}\text { V2 } \\
\text { (BRRIdhan 29) }\end{array}$ & \begin{tabular}{|l} 
V3 \\
(BRRIdhan 28)
\end{tabular} \\
\hline \multirow{5}{*}{ Mymensingh } & T1(Jan.21) & $5.77 \mathrm{a}$ & $6.00 \mathrm{a}$ & $6.62 \mathrm{a}$ \\
\hline & T2 (Feb.15) & $5.79 \mathrm{a}$ & $4.49 \mathrm{~b}$ & $6.26 \mathrm{a}$ \\
\hline & T3 (Mar.7) & $3.29 \mathrm{~b}$ & $3.68 \mathrm{c}$ & $2.48 \mathrm{c}$ \\
\hline & T4 (Mar.30) & $3.85 \mathrm{~b}$ & $2.04 \mathrm{~d}$ & $3.35 \mathrm{~b}$ \\
\hline & $L S D(5 \%)$ & & & \\
\hline \multirow{5}{*}{ Rangpur } & T1 & $6.29 \mathrm{~b}$ & $7.36 \mathrm{a}$ & $7.26 \mathrm{ab}$ \\
\hline & $\mathrm{T} 2$ & $8.05 \mathrm{a}$ & $7.20 \mathrm{a}$ & $8.71 \mathrm{a}$ \\
\hline & T3 & $4.84 \mathrm{bc}$ & $3.21 \mathrm{~b}$ & $5.82 \mathrm{~b}$ \\
\hline & T4 & $4.51 \mathrm{c}$ & $0.49 \mathrm{c}$ & $3.37 \mathrm{c}$ \\
\hline & $L S D(5 \%)$ & & & \\
\hline \multirow{5}{*}{ Ishwardi } & T1 & $5.71 \mathrm{a}$ & $7.04 \mathrm{a}$ & $5.66 \mathrm{a}$ \\
\hline & $\mathrm{T} 2$ & $5.24 \mathrm{a}$ & $7.59 \mathrm{a}$ & $4.32 \mathrm{~b}$ \\
\hline & T3 & $4.98 \mathrm{a}$ & $5.34 \mathrm{~b}$ & $5.94 \mathrm{a}$ \\
\hline & T4 & $5.54 \mathrm{a}$ & $6.99 \mathrm{a}$ & $5.03 \mathrm{ab}$ \\
\hline & $L S D(5 \%)$ & & & \\
\hline \multirow{5}{*}{ Cumilla } & T1 & $4.39 \mathrm{ab}$ & $6.47 \mathrm{a}$ & $3.83 \mathrm{~b}$ \\
\hline & $\mathrm{T} 2$ & $5.08 \mathrm{a}$ & $4.61 \mathrm{~b}$ & $5.27 \mathrm{a}$ \\
\hline & T3 & $4.00 \mathrm{~b}$ & $0.00 \mathrm{c}$ & $3.01 \mathrm{c}$ \\
\hline & T4 & $2.31 \mathrm{c}$ & $0.00 \mathrm{c}$ & $2.28 \mathrm{c}$ \\
\hline & $L S D(5 \%)$ & & & \\
\hline
\end{tabular}


Means with same letter are not statistically different at $5 \%$ probability level by LSD.

The transplanting date showed significant difference in yield for each cultivars in different locations (Table 2). For the cultivar V1, in general, the yield of second transplanting (T2) is slightly higher than that of first transplanting (T1), and gradually declines thereafter, except at Ishwardi location. For the cultivar V2, in general, the highest yield was obtained in first transplanting (T1), and then gradually declined, with the exception of Ishwardi location, where the second transplanting produced the highest and the last harvesting produced good yield. The yield of cultivar V3 is not consistent, first transplanting produced the highest at one location (Mymensingh), the second transplanting at two locations (Rangpur and Cumilla) and the third transplanting produced the highest yield at one location (Ishwardi).

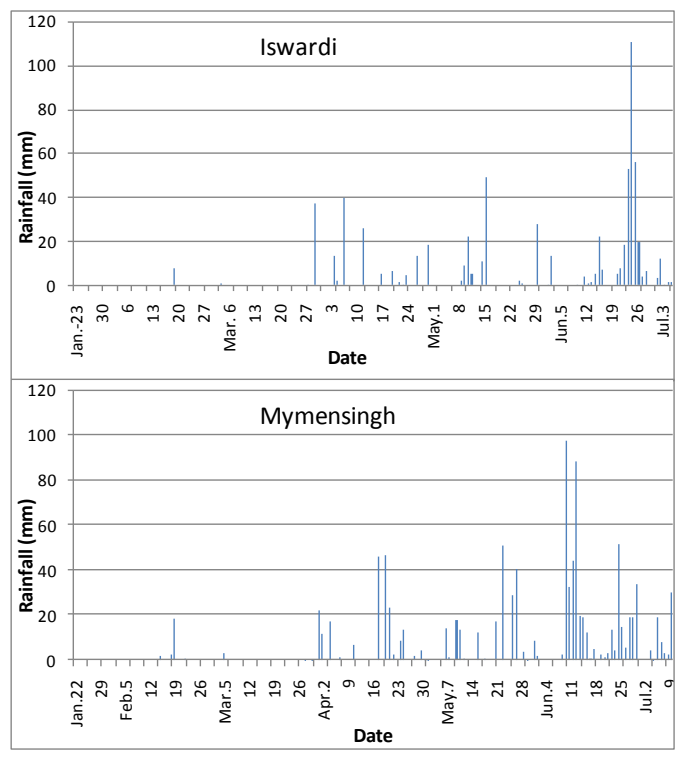

Figure 3: Rainfall distribution during rice growing period in 2015

The mean yields over locations and average crop duration are summarized in Table 2.2. In general, crop duration decreases with late transplanting dates, mainly due to higher heat units (Figure 2). The irrigation needed under different treatments (transplanting time) and cultivars is given in Table 2.3. The irrigation amount varied among locations, mainly due to variation of rainfall (Figure 3). The highest irrigation amount was needed at Rangpur location. Here, the first and second transplanting date (T1 and T2) needed almost similar irrigation, but the $3^{\text {rd }}$ and $4^{\text {th }}$ transplanting saved about $14 \%$ and $35 \%$ irrigation water compared to $1^{\text {st }}$ and $2^{\text {nd }}$ transplanting, coupled with declined yield (Table 2).

Table 2.2: Mean grain yield of cultivars at different locations under different transplanting dates (treatments) (2015)

\begin{tabular}{|c|c|c|c|c|c|c|c|}
\hline & & \multicolumn{4}{|c|}{ Yield (t/ha) } & \multirow{2}{*}{$\begin{array}{l}\text { Mean } \\
\text { yield } \\
\text { (t/ha) }\end{array}$} & \multirow{2}{*}{\begin{tabular}{|ll} 
Average & crop \\
duration & \\
(days), SS* &
\end{tabular}} \\
\hline & & $\begin{array}{l}\text { Mymen- } \\
\text { singh }\end{array}$ & Ishwardi & Rangpur & Cumilla & & \\
\hline \multirow{3}{*}{$\begin{array}{l}\mathrm{T}_{1} \\
\mathrm{D} / \mathrm{T}: \operatorname{Jan} .21\end{array}$} & V1 & 5.77 & 5.71 & 6.29 & 4.39 & 5.54 & 137 \\
\hline & V2 & 6.00 & 7.04 & 7.37 & 6.47 & 6.72 & 158 \\
\hline & V3 & 6.62 & 5.67 & 7.27 & 3.84 & 5.85 & 138 \\
\hline \multirow{3}{*}{$\begin{array}{l}\mathrm{T}_{2} \\
\text { D/T: Feb.15 }\end{array}$} & V1 & 5.80 & 5.24 & 8.06 & 5.08 & 6.05 & 131 \\
\hline & V2 & 4.94 & 7.60 & 7.20 & 4.61 & 6.09 & 152 \\
\hline & V3 & 6.26 & 4.32 & 8.71 & 5.27 & 6.14 & 131 \\
\hline \multirow{3}{*}{$\begin{array}{l}\mathrm{T}_{3} \\
\mathrm{D} / \mathrm{T}: \text { Mar.7 }\end{array}$} & V1 & 3.29 & 4.98 & 4.85 & 4.01 & 4.28 & 113 \\
\hline & V2 & 3.68 & 5.34 & 3.21 & 0 & 3.06 & 129 \\
\hline & V3 & 2.48 & 5.94 & 5.83 & 3.02 & 4.32 & 114 \\
\hline \multirow{3}{*}{$\begin{array}{l}\mathrm{T}_{4} \\
\mathrm{D} / \mathrm{T}: \text { Mar.30 }\end{array}$} & V1 & 3.85 & 5.55 & 4.52 & 2.32 & 4.06 & 120 \\
\hline & V2 & 2.04 & 7.00 & 0.49 & 0 & 2.38 & 140 \\
\hline & V3 & 3.35 & 5.03 & 3.37 & 2.28 & 3.51 & 121 \\
\hline
\end{tabular}

*SS means "Seed to seed"

\subsection{Year 2016}

The mean grain yields under different treatments (transplanting time) are summarized in Table 3.1. The interaction effects of treatments and varieties showed significant effects at two locations, Rangpur and Cumilla. For the cultivar V1, in general, the yields of $1^{\text {st }}$ and $2^{\text {nd }}$ transplanting (T1 and T2) are statistically similar, and gradually declines thereafter, except at Ishwardi location. For the cultivar V2, for all locations, the highest yield was obtained in first transplanting (T1), and then gradually declined.

For the cultivar V3, similar trend of V2, that is, the highest yield at $1^{\text {st }}$ transplanting and then gradually declined. For the cultivar V4, the yields of $1^{\text {st }}$ and $2^{\text {nd }}$ transplanting are statistically similar at three locations (Mymensingh, Rangpur and Ishwardi) and differed at one location. The irrigation needed under different treatments (transplanting time) and cultivars are given in Table 3. The irrigation amount varied among locations, mainly due to variation of rainfall (Figure 4). Average irrigation savings by $\mathrm{T}_{2} \mathrm{~V}_{1}$ compared to $\mathrm{T}_{1} \mathrm{~V}_{4}$ is $37 \%$, while the grain yield decreased by about $14 \%$ (Table 3 ). 


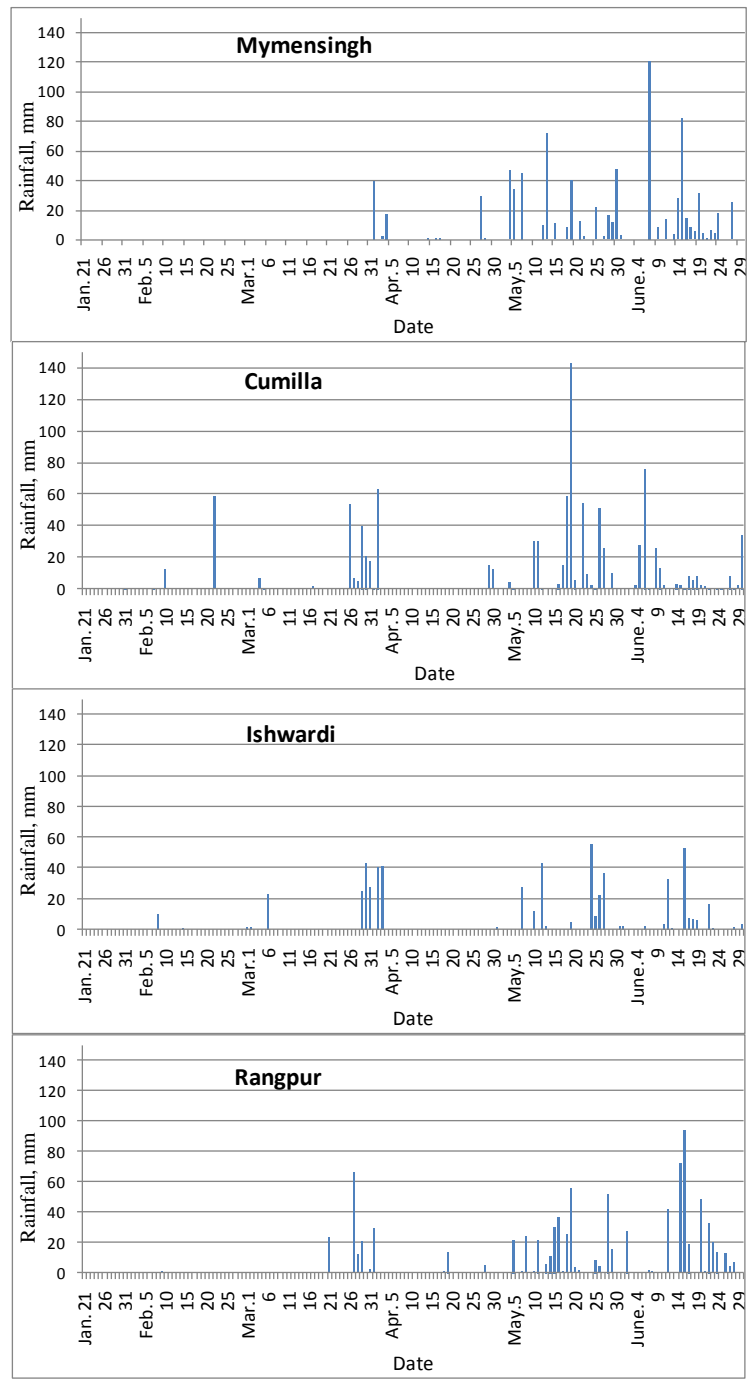

Figure 4: Rainfall distribution during rice growing period in 2016

\subsection{Considering the average yield and possible intrusion of addition Rabi crop between two rice crops}

Table 2.3: Irrigation amount needed at different locations (2015)

\begin{tabular}{|c|c|c|c|c|c|}
\hline & & \multicolumn{4}{|c|}{ Irrigation amount $(\mathrm{cm})$} \\
\hline & & Rangpur & $\begin{array}{l}\text { Mymen- } \\
\text { singh }\end{array}$ & Ishwardi & Cumilla \\
\hline \multirow{3}{*}{$\begin{array}{l}\mathrm{T}_{1} \quad(30 \text { DOS) } \\
\mathrm{D} / \mathrm{T}: 21-1-15\end{array}$} & V1 & 65 & 63 & 33 & 36 \\
\hline & V2 & 80 & 63 & 33 & 36 \\
\hline & V3 & 65 & 63 & 33 & 36 \\
\hline \multirow{3}{*}{$\begin{array}{l}\mathrm{T}_{2}(26 \text { DOS }) \\
\mathrm{D} / \mathrm{T}: 15-2-15\end{array}$} & V1 & 66 & 29 & 24 & 36 \\
\hline & V2 & 71 & 29 & 24 & 36 \\
\hline & V3 & 66 & 29 & 24 & 36 \\
\hline \multirow{3}{*}{$\begin{array}{l}\mathrm{T}_{3}(25 \mathrm{DOS}) \\
\mathrm{D} / \mathrm{T}: 7-3-15\end{array}$} & V1 & 56 & 50 & 24 & 39 \\
\hline & V2 & 56 & 50 & 24 & 39 \\
\hline & V3 & 56 & 50 & 24 & 39 \\
\hline \multirow{3}{*}{$\begin{array}{l}\mathrm{T}_{4}(25 \mathrm{DOS}) \\
\mathrm{D} / \mathrm{T}: 30-3-15\end{array}$} & V1 & 42 & 39 & 23 & 39 \\
\hline & V2 & 42 & 39 & 23 & 39 \\
\hline & V3 & 42 & 39 & 23 & 39 \\
\hline
\end{tabular}

The mean yields over locations and years are summarized in Table 4. Generally, the yield of all cultivars at first and second transplanting (i.e. in T1 \& T2) are good and decrease at the later transplanting dates (T3, T4). So, optimization should be made between these two dates and the cultivars considering yield, irrigation water savings, and possible intrusion of addition Rabi crop between two rice crops.

Table 3.1: Effect of treatments (transplanting time) on grain yield at each level of cultivars (2016)

\begin{tabular}{|l|l|l|l|l|l|}
\hline \multirow{5}{*}{ Mymensingh } & \multirow{4}{*}{ Treatment } & Cultivars & \multicolumn{4}{l|}{} \\
\cline { 3 - 6 } & & $\begin{array}{l}\text { V1 } \\
\text { (Binadhan-14) }\end{array}$ & $\begin{array}{l}\text { V2 } \\
\text { (BRRIdhan 29) }\end{array}$ & $\begin{array}{l}\text { V3 } \\
\text { (BRRIdhan 28) }\end{array}$ & $\begin{array}{l}\text { V4 } \\
\text { (Binadhan-10) }\end{array}$ \\
\hline \multirow{5}{*}{} & T1(Jan.21) & 5.12 & 6.13 & 5.28 & 5.57 \\
\cline { 2 - 6 } & T2 (Feb.15) & 5.18 & 5.76 & 5.22 & 4.42 \\
\cline { 2 - 6 } & T3 (Mar.7) & 4.13 & 4.82 & 3.67 & 3.95 \\
\cline { 2 - 6 } & T4 (Mar.30) & 4.94 & 4.99 & NS & NS \\
\cline { 2 - 6 } & LSD (5\%) & NS & NS & NS & $7.12 \mathrm{a}$ \\
\hline & T1 & $5.74 \mathrm{a}$ & $7.04 \mathrm{a}$ & $6.60 \mathrm{a}$ & \multicolumn{2}{l}{} \\
\hline
\end{tabular}




\begin{tabular}{|l|l|l|l|l|l|}
\hline \multirow{5}{*}{ Rangpur } & $\mathrm{T} 2$ & $5.62 \mathrm{a}$ & $5.04 \mathrm{~b}$ & $5.79 \mathrm{a}$ & $6.94 \mathrm{a}$ \\
\cline { 2 - 6 } & $\mathrm{T} 3$ & $5.78 \mathrm{a}$ & $1.69 \mathrm{c}$ & $6.76 \mathrm{a}$ & 4.77 \\
\cline { 2 - 6 } & $\mathrm{T} 4$ & $2.15 \mathrm{~b}$ & $0.65 \mathrm{c}$ & $1.53 \mathrm{~b}$ & $0.97 \mathrm{c}$ \\
\cline { 2 - 6 } & LSD (5\%) & & & & \\
\hline \multirow{5}{*}{ Sumwardi } & $\mathrm{T} 1$ & 6.02 & 5.53 & 5.32 & 6.99 \\
\cline { 2 - 6 } & $\mathrm{T} 2$ & 6.19 & 5.35 & 4.70 & 7.08 \\
\cline { 2 - 6 } & $\mathrm{T} 3$ & 6.26 & 5.14 & 5.04 & 7.02 \\
\cline { 2 - 6 } & $\mathrm{T} 4$ & 6.87 & 5.04 & 4.91 & 6.96 \\
\cline { 2 - 6 } & LSD (5\%) & $\mathrm{NS}$ & $\mathrm{NS}$ & $\mathrm{NS}$ & $\mathrm{NS}$ \\
\hline & $\mathrm{T} 1$ & $4.98 \mathrm{a}$ & $6.05 \mathrm{a}$ & $4.84 \mathrm{a}$ & $6.39 \mathrm{a}$ \\
\cline { 2 - 6 } & $\mathrm{T} 2$ & $4.74 \mathrm{a}$ & $5.46 \mathrm{a}$ & $3.99 \mathrm{a}$ & $4.03 \mathrm{~b}$ \\
\cline { 2 - 6 } & $\mathrm{T} 3$ & $3.09 \mathrm{~b}$ & $2.10 \mathrm{~b}$ & $1.93 \mathrm{~b}$ & $2.22 \mathrm{c}$ \\
\cline { 2 - 6 } & $\mathrm{T} 4$ & $2.58 \mathrm{~b}$ & $0.00 \mathrm{c}$ & $1.58 \mathrm{~b}$ & $2.62 \mathrm{c}$ \\
\cline { 2 - 6 } & LSD (5\%) & & & & \\
\hline
\end{tabular}

Note: Means with the same letter are not significantly different by LSD at 5\% level.

Table 3.2: Irrigation water requirement (cm) under different transplanting time at each level of cultivars (2016)

\begin{tabular}{|c|c|c|c|c|c|c|}
\hline \multirow[t]{2}{*}{ Treatment } & \multirow[t]{2}{*}{ Cultivar } & \multicolumn{5}{|c|}{ Water requirement $(\mathrm{cm})$} \\
\hline & & Cumilla & Mym & Iswardi & Rangpur & Average \\
\hline \multirow[t]{4}{*}{$\mathrm{T} 1$} & V1 & 34 & 36 & 47 & 78 & 49 \\
\hline & V2 & 34 & 36 & 47 & 83 & 50 \\
\hline & V3 & 34 & 36 & 47 & 78 & 49 \\
\hline & V4 & 34 & 40 & 50 & 93 & 54 \\
\hline \multirow[t]{4}{*}{$\mathrm{T} 2$} & V1 & 23 & 36 & 39 & 60 & 40 \\
\hline & V2 & 23 & 36 & 39 & 75 & 43 \\
\hline & V3 & 23 & 36 & 39 & 60 & 40 \\
\hline & V4 & 23 & 36 & 52 & 110 & 55 \\
\hline \multirow[t]{4}{*}{$\mathrm{T} 3$} & V1 & 19 & 27 & 40 & 82 & 42 \\
\hline & V2 & 19 & 27 & 40 & 92 & 45 \\
\hline & V3 & 19 & 27 & 40 & 82 & 42 \\
\hline & V4 & 19 & 27 & 52 & 92 & 48 \\
\hline \multirow[t]{4}{*}{$\mathrm{T} 4$} & V1 & 0 & 32 & 40 & 59 & 33 \\
\hline & V2 & 0 & 32 & 40 & 69 & 35 \\
\hline & V3 & 0 & 32 & 40 & 59 & 33 \\
\hline & V4 & 0 & 32 & 46 & 69 & 37 \\
\hline
\end{tabular}

Table 4.1: Mean yield over locations and years under different transplanting time at each level of cultivars

\begin{tabular}{|l|l|l|}
\hline Treatment & Cultivar & Mean yield (t/ha) \\
\hline \multirow{5}{*}{ T1 } & V1 & $\mathbf{5 . 5 0}$ \\
\cline { 2 - 3 } & V2 & 6.45 \\
\cline { 2 - 3 } & V3 & 5.68 \\
\cline { 2 - 3 } & V4 & 6.52 \\
\hline T2 & V1 & $\mathbf{5 . 7 4}$ \\
\cline { 2 - 3 } & V2 & 5.75 \\
\cline { 2 - 3 } & V3 & 5.53 \\
\cline { 2 - 3 } & V4 & 5.62 \\
\hline \multirow{4}{*}{ T3 } & V1 & $\mathbf{4 . 5 5}$ \\
\cline { 2 - 3 } & V2 & 3.25 \\
\cline { 2 - 3 } & V3 & 4.33 \\
\cline { 2 - 3 } & V4 & 4.49 \\
\hline T4 & V1 & $\mathbf{4 . 1 0}$ \\
\cline { 2 - 3 } & V2 & 2.53 \\
\cline { 2 - 3 } & V3 & 3.28 \\
\cline { 2 - 3 } & V4 & 3.75 \\
\hline
\end{tabular}

Table 4.2: Water savings ( $\mathrm{cm}$ ) in $\mathrm{T} 2$ compared to $\mathrm{T} 1$

\begin{tabular}{|l|l|l|l|l|l|}
\hline \multirow{2}{*}{ Year } & Cultivar & \multicolumn{2}{|l|}{ Water savings, cm } \\
\cline { 3 - 6 } & & Cumilla & Mymensingh & Ishwardi & Rangpur \\
\hline 2015 & V1 & 0 & 34 & 9 & -1 \\
\hline
\end{tabular}




\begin{tabular}{|l|l|l|l|l|l|}
\hline \multirow{5}{*}{} & V2 & 0 & 34 & 9 & 9 \\
\cline { 2 - 6 } & V3 & 0 & 34 & 9 & -1 \\
\hline \multirow{3}{*}{2016} & & & & & \\
\cline { 2 - 6 } & V1 & 11 & 0 & -2 & 18 \\
\cline { 2 - 6 } & V2 & 11 & 0 & 8 & -17 \\
\cline { 2 - 6 } & V3 & 11 & 0 & 8 & 8 \\
\cline { 2 - 6 } & V4 & 11 & & 8 & \\
\hline
\end{tabular}

In many areas of Bangladesh, two crops are grown in a year, and thus the land becomes free at first transplanting time. But the major land-type of Bangladesh is medium land, and in such areas, one Rabi crop (pulses, oil-seeds, potato or wheat) can be grown between two rice crops in a yearly cycle, and hence possibilities of increasing cropping intensity of the country. In such case, the land will be free at second transplanting time. In this case, the high performing cultivars at first transplanting (V1 and V4, Table 4) have to be sacrificed to gain additional Rabi crop, and irrigation savings in second transplanting (T2) compare to first one (T1). In second transplanting, the cultivar V1 and V2 produced almost similar yield. So, any of this cultivars can be grown. When we consider the irrigation savings in T2 compared to T1 (Table 4), the irrigation savings varies with location and year, mainly due to variation of rainfall amount and distribution. The crop duration of the cultivar also plays a role. The general tendency is that, the second transplanting can save irrigation water. When we consider the crop duration of cultivar V1 and V2 (Table 2), the V1 is shorter duration, and hence should be used (as the yield is similar).

By considering economic factor (intrusion of additional rabi crop between two rice crops) and ecological factor (irrigation reduction, and hence reducing groundwater withdrawal), we recommend that the most suitable transplanting time for Boro rice should be $15^{\text {th }}$ February. As such, we can effectively achieve good yield, reduce irrigation requirement, and creating opportunity for possible intrusion of addition Rabi crop between two rice crops. Overall, the findings of the present study can provide effective transplanting time and cultivar to reduce groundwater withdrawal in the present agro-ecosystem of northwestern Bangladesh and other similar areas.

\subsection{Conclusion}

As surface water supply is decreasing day by day, irrigation pressure is going towards groundwater resource. Judicious withdrawal of groundwater in intensive irrigated area is a crucial need for maintaining sustainability of the resource. Field experiments were conducted of Boro rice cultivars in different planting dates with respect to yield and irrigation water requirement, and to optimize between yield and irrigation water requirement, with a view to reduce groundwater withdrawal and hence reducing mining of groundwater. The results showed that in general, the yield of all cultivars at first and second transplanting are good and decreased at the later transplanting dates, which could not be recommended among farmers. When we consider the irrigation savings in second transplanting compared to first one, the irrigation savings varies with location and year, but the general tendency is that the second transplanting can save irrigation water. The cultivar Binadhan-14 (V1) can be selected for its good yield at second transplanting and short duration. By considering economic actor (intrusion of additional rabi crop between two rice crops) and ecological factor (irrigation reduction, and hence lower groundwater withdrawal), we recommend that the most suitable transplanting time for Boro rice should be 15th February. In this case, we can achieve good yield, reduce irrigation requirement, and create opportunity for possible intrusion of addition Rabi crop between two rice crops. The findings of the present study can help in selecting transplanting time and cultivar to reduce groundwater withdrawal in the present agro-ecosystem of northwestern Bangladesh and other similar areas.

\section{References}

[1] M. Kuper, H. Amichi, M. Pierre-Louis, “Groundwater use in North Africa as a cautionary tale for climate change adaptation," 725-740, 2016. doi: $10.1080 / 02508060.2017 .1351058$

[2] P. Cullet, and R.M. Stephan, "Introduction to 'Groundwater and Climate Change: Multi-level Law and Policy Perspectives. Water International, Vol. 42, 6, 641-645, 2017. DOI: $10.1080 / 02508060.2017 .1358960$

[3] M. Sadia, and M.H. Ali, "Recent trend of reference evapotranspiration in the north-eastern region of Bangladesh," Journal of Basic and Applied Res. Int., Vol. 19(1), 10-19, 2016.

[4] M.H. Ali, "Environmental and economic aspects of excessive groundwater withdrawal In: Andrew C. Briggs (Edit.) Water Shortages: Environmental, Economic and Social Impacts," Nova Science Publishers, Inc, NY, USA, pp. 177-194, 2010a.

[5] A.A. Sarkar, M.H. Ali, "Water-table dynamics of Dhaka city and its long-term trend analysis using the "MAKESENS" model," Water International, Vol. 34(3), 373-382, 2009.

[6] M.H. Ali, “Introduction - perspectives and general concept of irrigation," In: Fundamentals of Irrigation \& On-farm Water Management, Vol. 1. SpringerVerlag, New York, pp.1-10, 2010b.

[7] M.H. Zaman, X. Song, D. Han, Y. Zhang, S. Hussain, "Prediction of Groundwater Dynamics for Sustainable Water Resource Management in Bogra District, Northwest Bangladesh," Water, Vol. 9, 237-254, 2017.

[8] T. Asraf, and M.H. Ali, "Water-table dynamics and trend in three Upazilas of Rajshahi district (Barind area), Bangladesh," Asian Academic Research Journal of Multidisciplinary, Vol. 2(6), 286 -310, 2015.

[9] M.H. Ali, A.A. Sarkar, and M.A. Rahman, "Analysis on groundwater-table declination and quest for sustainable water use in the North-western region (Barind area) of Bangladesh," J. of Agril. Sci. and Applications, Vol. 1(1), 26-32, 2012.

[10] A.K.M.R. Islam, M.H. Ali, and M.G.M. Amin, "Long-term variability of rainfall at different agro-ecological regions of Bangladesh," J. Bangladesh Soc. Agril. Sci. Technol., Vol. 1(1\&2), $19-24,2004$.

[11] M.H. Ali, A.K.M. Adham, and M. Rahman, "Impact of climate change on crop water demand and its implication on water resources planning," J. Agrometeorol., Vol. 9(1), 20-25, 2007.

[12] BINA, "Comparative assessment of water saving in Binadhan-14 (A Braus variety). In: Annual Report for 201-16, Bangladesh Institute of Nuclear Agriculture, Mymensingh, Bangladesh, pp.19-21, 2016.

[13] SAIC (SAARC Agriculture Information Center). "IRRI developed technology for producing irrigated rice with less water. SAIC Newsletter," A quality publication of SAARC agriculture center, Vol. 17(2), 4-6, 2007.

[14] M.H. Ali, I. Abustan, M.A. Rahman, and A.A.M. Haque, "Sustainability of Groundwater Resources in the North-Eastern Region of Bangladesh," Water Resour. Manage, Vol. 26, 623-641, 2011.

[15] A.K.M. Adham, M.H. Ali, and F. Khanam, "Solar radiation and potential crop production at Comilla region of Bangladesh," J. Bangladesh Agril. Univ, Vol. 
3(1), Pp. 149 - 154, 2005.

[16] M.H. Ali, A.K.M. Adham, and M.S.U. Talukder, "Solar radiation and potential crop production at Mymensingh," Bangladesh J. Agril. Sci., Vol. 31(2), 239 $243,2004$.

[17] M.G.M. Amin, M.H. Ali, and A.K.M.R. Islam, "Agro-climatic analysis for crop planning in Bangladesh," Bangladesh J. Agri. Engg. Vol. 15(1\& 2), 31- 40, 2004.

[18] M.H. Ali, M.G.M. Amin, and A.K.M.R. Islam, "Probability analysis of monsoon and off-monsoon rainfall and crop planning in Bangladesh,” Bangladesh J. Env. Sci., Vol. 11(2), 290 - 295, 2005.

[19] M.H. Ali, I. Abustan, M.H. Zaman, A.K.M.R. Islam, A. AlBassam, "Optimising irrigation water for field crops to maximize the yield and economic return," Global Advanced Research Journal of Agricultural Science, Vol. 3(8), 223-232, 2014.

[20] L. Hai-dong, J. Xue, and D. Guo, "Efficacy of planting date adjustment as a cultivation strategy to cope with drought stress and increase rainfed maize yield and water-use efficiency," Agric. Water Manage, Vol. 179, 227-235, 2017.

[21] P. Paredes, G.C. Rodrigues, M. do R. Cameira, M.O. Torres, Luis S. Pereira, "Assessing yield, water productivity and farm economic returns of malt barley as influence by the sowing dates and supplemental irrigation," Agric. Water Manage., Vol. 179, 132-143, 2017.

[22]M.A. Tahir, M.A. Arain, S. Durrani, A. Shakoor, A. Bilal, A. Ali, M. Ishfaq, U. Farooq, S. Ahmad, M. Irfan, "Evaluating the Optimum Transplanting Time for Different Coarse Rice Genotypes under Semi-Arid Conditions of Faisalabad," Agricultural Sciences, Vol. 9, 69-77, 2018.

[23] A.A. Sarkar, M.H. Zaman, M.A. Rahman, M.J.Nain, N.M.Karim, M. H. Ali, "Increasing cropping intensity and profitability in dry Barind area of Bangladesh, utilizing profile soil moisture and supplemental irrigation," Bangladesh J. Nuclear Agric., Vol. 27 (28), 103-118, 2013.

[24] M.H. Ali, "Plant - a media of water absorption," In: Fundamentals of Irrigation \& On-farm Water Management, Vol 1. Springer-Verlag, New York, pp. 399-453, 2010c.

[25] K.C. Waha, A. Mulllar, J.P. Bondeau, P. Dietrich, J. Kurukulasuriy, H. Heinke Lotze-Campen, "Adaptation to climate change through the choice of cropping system and sowing date in sub-Saharan Africa," Global Environ. Change, Vol. 23, 130-143, 2013. 